NATIONAL WATER-QUALITY ASSESSMENT PROGRAM

\title{
Ecological Indicators of Water Quality in the Spokane River, Idaho and Washington, 1998 and 1999
}

\section{Background}

Urban and mining activities have affected the Spokane River that flows out of Coeur d'Alene Lake from Idaho into Washington. This large river (more than 150 feet wide) flows through the city of Spokane to the 7 Mile bridge site and is impounded by three dams used to generate hydroelectric power. From Spokane, the river continues west and joins the Columbia River 63 miles downstream. Historical and current mining activities in the Coeur d'Alene River Basin in Idaho have contributed large quantities of metals to Coeur d'Alene Lake (Grosbois and others, 2001). The USGS has documented elevated concentrations of cadmium, lead, and zinc entering the river from Coeur d'Alene Lake (Woods, 2000). The WDOE has placed the Spokane River on its 303(d) impaired water list (Clean Water Act) for high concentrations of trace metals that violate Washington's waterquality criteria (Washington State Department of Ecology, accessed May 1, 2003, at http://www.ecy.wa.gov/ programs/wq/303d/1998/1998_by_wrias.html. In addition, studies done by the WDOE (1995) and USGS (MacCoy, 2001) have identified elevated concentrations of PCBs in fish and sediments.
The USGS, in cooperation with WDOE, sampled six sites along the Spokane River during the summers of 1998 and 1999 to evaluate urban and mining impacts on aquatic organisms (fig. 1). This study of the Spokane River was conducted as part of the NROK NAWQA Program to evaluate the status and trends in surface- and ground-water quality in parts of western Montana, northern Idaho, and eastern Washington (Tornes, 1997).

Ecological indicators were evaluated to determine the effects of multiple stressors on aquatic organisms. The ecological data collected at these sites are outlined in the sampling matrix table (table 1). The purpose of this study was to:
- Identify surface-water-quality and sedimentquality constituents of concern and determine whether those constituents were affecting aquatic organisms.

- Conduct a baseline aquatic community assessment at selected Spokane River sites.

- Compare aquatic community measures and metrics with those at least-impacted sites.

- Analyze contaminants in aquatic organisms and sediment and compare the results with established criteria. 


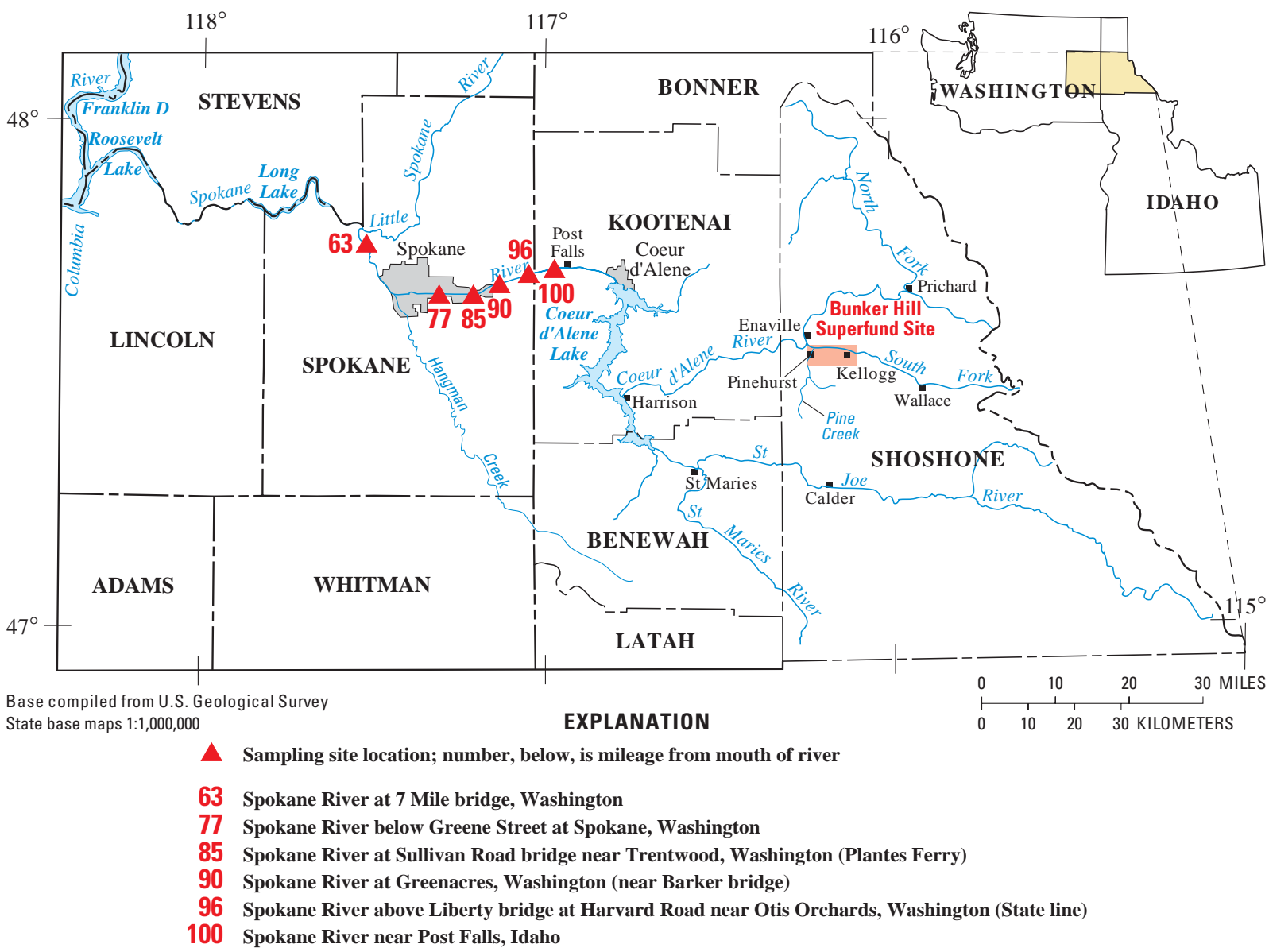

Figure 1. Locations of sampling sites, Bunker Hill Superfund site, and the Spokane River Basin, Idaho and Washington.

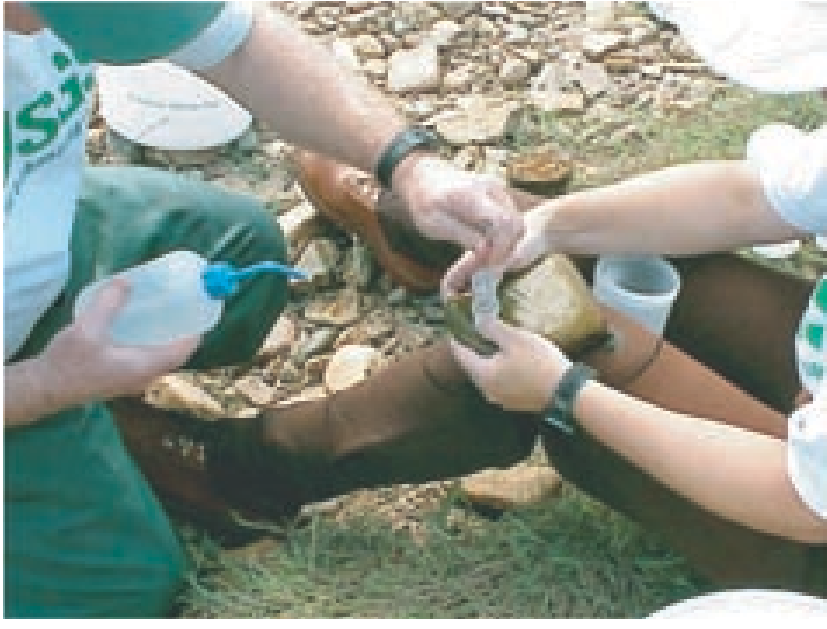

Figure 2. Periphyton (algae attached to bottom substrate) were collected from riffle areas using protocols described by Porter and others (1993).

\section{Periphyton}

Samples of periphyton (algae attached to bottom substrate) were collected at all sites for analysis of CHLA (fig. 2). The concentration of CHLA in a sample indicates the level of nutrients in the river that are available to promote algal growth. Concentrations of CHLA between 100 and 150 milligrams per square meter $\left(\mathrm{mg} / \mathrm{m}^{2}\right)$ have been suggested as an indicator of nuisance algal conditions (Welch and others, 1989; Watson and Gestring, 1996).

The Spokane River did not appear to be waterquality limited as a result of excessive algal growth at sites sampled during this study; however, the downstream CHLA concentration approached the nuisance level. At the upstream sites in the Spokane River, CHLA concentrations were between 2 and 10 $\mathrm{mg} / \mathrm{m}^{2}$, far below levels of nuisance algal growth. At the downstream site at the 7 Mile bridge, below sewage-treatment facilities and other industrial inputs, the CHLA concentration was $94 \mathrm{mg} / \mathrm{m}^{2}$, which is approaching the nuisance level. 
Table 1. Sampling matrix of ecological data collected by the USGS during 1998 and 1999 from selected sites on the Spokane River, Idaho and Washington, for a cooperative study with WDOE and for the NROK NAWQA Program.

[Locations of sampling sites shown in figure 1; O, samples collected in 1998; X, samples collected in 1999; X, data analyzed by WDOE ${ }^{1}$. Data analyzed by USGS for this study can be accessed at http://idaho.usgs.gov/projects/spokane/index.html]

\begin{tabular}{|c|c|c|c|c|c|c|}
\hline & \multicolumn{6}{|c|}{ Site name } \\
\hline & Post Falls & $\begin{array}{l}\text { Otis Orchards } \\
\text { (State line) }\end{array}$ & Greenacres & $\begin{array}{c}\text { Sullivan Road } \\
\text { bridge }\end{array}$ & Greene Street & 7 Mile bridge \\
\hline River mile & 100 & 96 & 90 & 85 & 77 & 63 \\
\hline USGS site ID & 12419000 & 12419500 & 12420500 & 12420800 & 12422000 & 12424500 \\
\hline $\begin{array}{l}\text { Latitude } \\
\text { Longitude }\end{array}$ & $\begin{aligned} 47^{\circ} 42^{\prime} 11^{\prime \prime} \\
116^{\circ} 58^{\prime} 37^{\prime \prime}\end{aligned}$ & $\begin{array}{r}47^{\circ} 40^{\prime} 56^{\prime \prime} \\
117^{\circ} 05^{\prime} 05^{\prime \prime}\end{array}$ & $\begin{aligned} 47^{\circ} 40^{\prime} 45^{\prime \prime} \\
117^{\circ} 09^{\prime} 25^{\prime \prime}\end{aligned}$ & $\begin{array}{r}47^{\circ} 40^{\prime} 40^{\prime \prime} \\
117^{\circ} 11^{\prime} 43^{\prime \prime}\end{array}$ & $\begin{array}{r}47^{\circ} 40^{\prime} 40^{\prime \prime} \\
117^{\circ} 222^{\prime} 20^{\prime \prime}\end{array}$ & $\begin{array}{l}47^{\circ} 44^{\prime} 25^{\prime \prime} \\
117^{\circ} 31^{\prime} 10^{\prime \prime}\end{array}$ \\
\hline Periphyton (chlorophyll- $a$ and biomass) & $\mathrm{X}$ & $\mathrm{X}$ & $\mathrm{X}$ & $\mathrm{X}$ & $\mathrm{X}$ & $\mathrm{X}$ \\
\hline Macroinvertebrate community & OX & $\mathrm{X}$ & $\mathrm{X}$ & $\mathrm{X}$ & $\mathrm{X}$ & $\mathrm{X}$ \\
\hline Fish community & OX & $\mathrm{X}$ & & $\mathrm{X}$ & $\mathrm{X}$ & OX \\
\hline Habitat assessment & $\mathrm{X}$ & & & & & $\mathrm{X}$ \\
\hline $\begin{array}{l}\text { Continuous (hourly) summer water } \\
\text { temperature }\end{array}$ & OX & $\mathrm{X}$ & & & $\mathrm{X}$ & $\mathrm{X}$ \\
\hline Trace metals-macroinvertebrates & $\mathrm{X}$ & $\mathrm{X}$ & $\mathrm{X}$ & $\mathrm{X}$ & $\mathrm{X}$ & $\mathrm{X}$ \\
\hline Trace metals-fish tissue & $\mathrm{X}$ & $\mathrm{X}$ & & $\mathrm{X}$ & & OX \\
\hline Organochlorines-fish tissue & $\mathrm{X}$ & $\mathrm{X}$ & & $\mathrm{X}$ & & $\mathrm{O}$ \\
\hline Trace metals-sediment & OX & & & & & OX \\
\hline Organochlorines-sediment & OX & & & & & OX \\
\hline $\begin{array}{l}\text { Trace metals and PCBs-whole rainbow trout, } \\
\text { largescale suckers, and mountain whitefish }{ }^{1}\end{array}$ & & $\mathrm{X}$ & & $\mathrm{X}$ & $\mathrm{X}$ & $\mathrm{X}$ \\
\hline
\end{tabular}

${ }^{1}$ See the WDOE home page (http://www.ecy.wa.gov/) for further details about their sampling effort on the Spokane River.

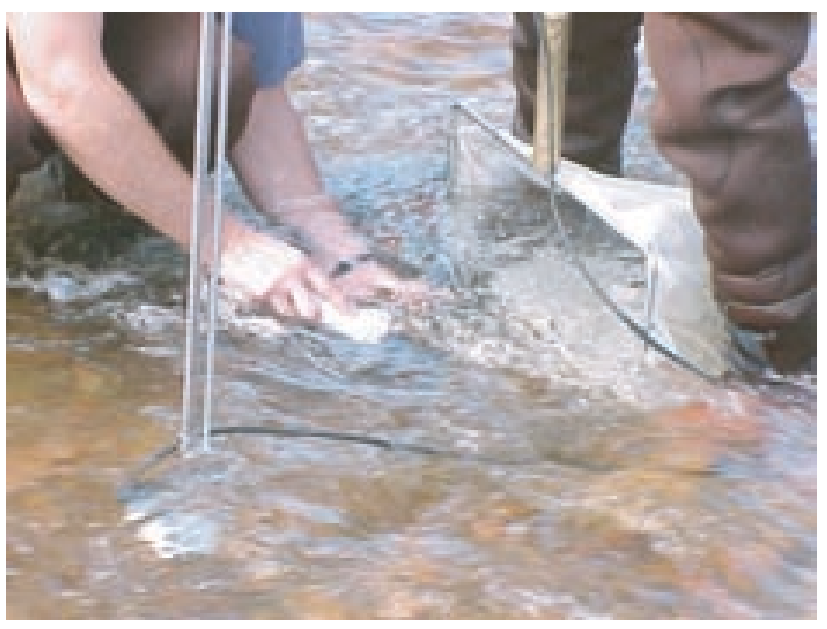

Figure 3. Macroinvertebrates were sampled at all sites in the Spokane River using protocols described by Cuffney and others (1993).

\section{Macroinvertebrate Community}

Macroinvertebrates were collected from riffle habitats for community assessment and analysis of metal concentrations in caddisflies (fig. 3). Even though the total abundance of macroinvertebrates collected in 1999 at the Spokane River sites was higher than at least-impacted sites (sites upstream from urban and mining impacts sampled as part of the NROK NAWQA) on the North Fork Coeur d'Alene River at Enaville and the St. Joe River near Calder (Maret and others, 2001), the number of individual taxa (indicating biological diversity) was much lower. In fact, the number of mayflies (Ephemeroptera), stoneflies (Plecoptera), and caddisflies (Trichoptera), referred to as EPT taxa, was 2 to 3 times lower at Spokane River sites than at least-impacted sites (fig. 4). Stoneflies that are found at most least-impacted sites in 


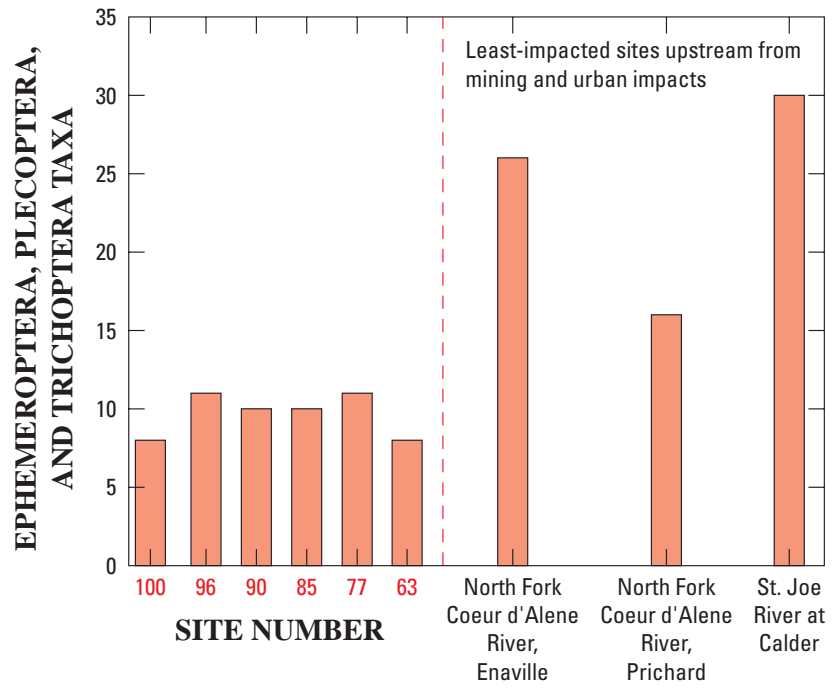

Figure 4. Ephemeroptera, Plecoptera, and Trichoptera taxa collected in the Spokane River, Idaho and Washington, compared with taxa collected at least-impacted sites, Idaho. (Site numbers shown in figure 1; data for least-impacted sites are given in report by Maret and others, 2001)

Idaho were absent from the Spokane River. On the basis of regional collections by Maret and others (2001), the Spokane River should be able to support at least five taxa of stoneflies. Even though measures of substrate (bottom material such as gravel or cobbles) size and percent embeddedness (amount of fine substrate surrounding larger substrate) did not indicate habitat degradation and were very low (less than 10 percent) for riffle habitats at all sampling sites, the low numbers of EPT taxa in the Spokane River indicated impaired water quality.

\section{Fish Community}

Fish were collected at each site as indicated in table 1. The fish were weighed, measured, and examined for anomalies (such as deformities, eroded fins, lesions, and tumors) using protocols described by Meador and others (1993). The fish species collected from the Spokane River are listed in table 2.

Salmonids will experience adverse health effects when exposed to temperatures outside their optimal range (U.S. Environmental Protection Agency, 2002) because they are coldblooded and their survival depends on external water temperatures. The Spokane River historically supported a strong native salmonid population (Youngs, 1996). The State of Washington has classified the Spokane River as "excellent" between river miles 58 and 96 (below the 7 Mile bridge site to the Idaho/Wash-

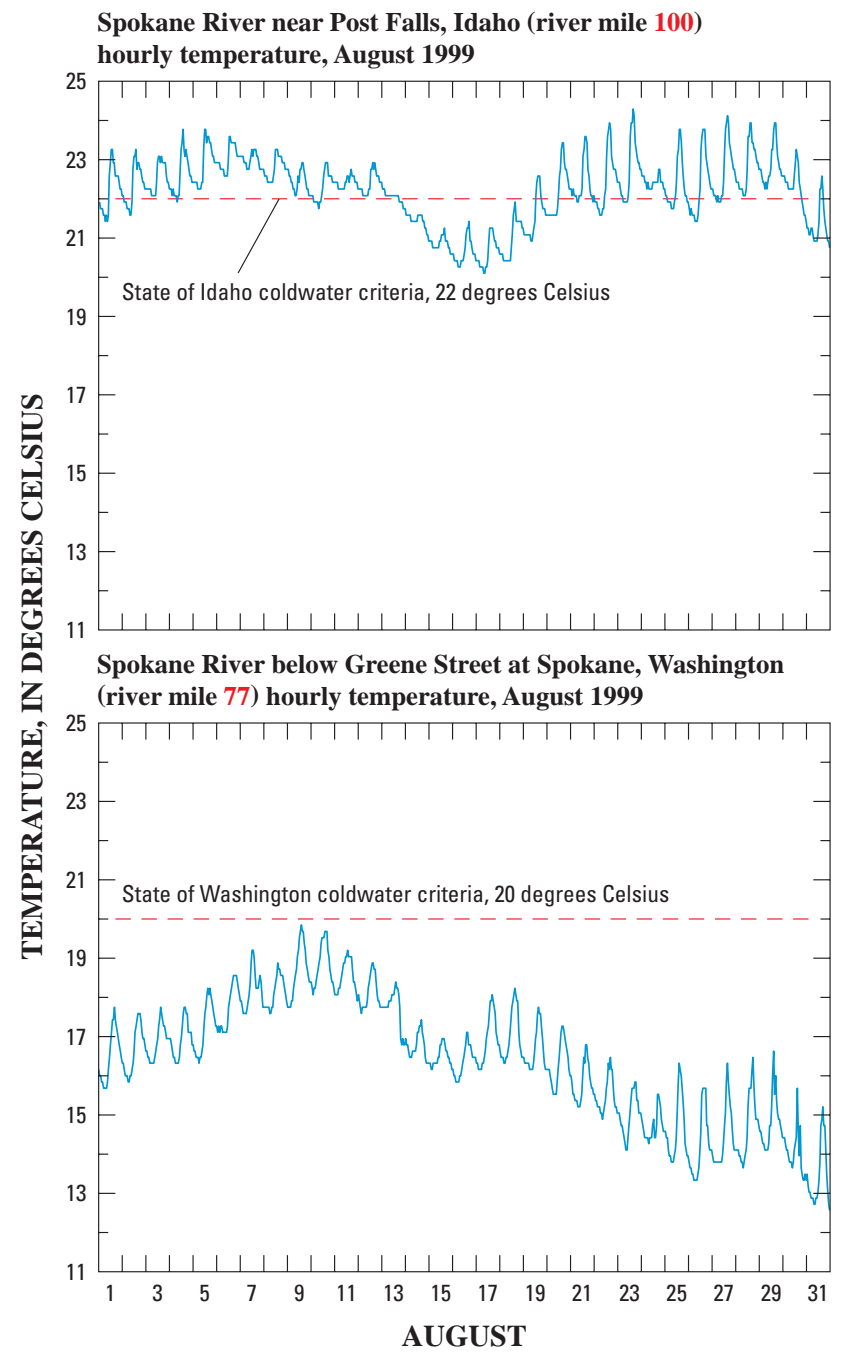

Figure 5. Hourly temperature measurements at Spokane River near Post Falls, Idaho, and Spokane River below Greene Street at Spokane, Washington, August 1999.

ington State line), meaning that water quality in this reach must meet or exceed goals for all uses, including salmon migration, rearing, spawning, and harvesting. In an effort to meet these goals, a temperature criterion of 20 degrees Celsius has been set for protection of coldwater species in this reach of the river (Washington State Department of Ecology, 1997). Idaho's criterion for the protection of coldwater aquatic organisms is 22 degrees Celsius (Idaho Department of Environmental Quality, accessed January 28, 2003, at http://www2.state.id.us/ adm/adminrules/rules/idapa58/58index.htm).

The upstream part of the Spokane River receives water from the surface of Coeur d'Alene Lake that is warmer than the river water. Coeur d'Alene Lake is a natural lake and outflow is controlled by Post Falls Dam. During the summer months, water temperature in the 
Table 2. Number of fish species collected at selected reaches on the Spokane River, Idaho and Washington, 1998 and 1999

[Samples collected in 1998 unless otherwise indicated]

\begin{tabular}{|c|c|c|c|c|c|c|c|}
\hline \multirow[b]{2}{*}{ Family } & \multicolumn{7}{|c|}{ Site name } \\
\hline & $\begin{array}{l}\text { Post } \\
\text { Falls }\end{array}$ & $\begin{array}{l}\text { Post } \\
\text { Falls } \\
(1999)\end{array}$ & $\begin{array}{c}\text { Otis } \\
\text { Orchards } \\
\text { (State line) }\end{array}$ & $\begin{array}{l}\text { Sullivan } \\
\text { Road } \\
\text { bridge }\end{array}$ & $\begin{array}{l}\text { Greene } \\
\text { Street }\end{array}$ & $\begin{array}{l}7 \text { Mile } \\
\text { bridge }\end{array}$ & $\begin{array}{l}7 \text { Mile } \\
\text { bridge } \\
(1999)\end{array}$ \\
\hline $\begin{array}{l}\text { Salmonidae } \\
\text { (trout and } \\
\text { whitefish) }\end{array}$ & & & 1 & 4 & 2 & 2 & 2 \\
\hline $\begin{array}{l}\text { Cottidae } \\
\text { (sculpins) }\end{array}$ & & 1 & 1 & & & 1 & \\
\hline $\begin{array}{l}\text { Catostomidae } \\
\text { (suckers) }\end{array}$ & 1 & 1 & 1 & 2 & 1 & 2 & 2 \\
\hline $\begin{array}{l}\text { Cyprinidae } \\
\text { (minnows and } \\
\text { carp) }\end{array}$ & 3 & 3 & 3 & 3 & 2 & 4 & 2 \\
\hline $\begin{array}{l}\text { Centrarchidae } \\
\text { (sunfish) }\end{array}$ & 4 & 1 & & & 1 & & \\
\hline $\begin{array}{l}\text { Ictaluridae } \\
\text { (catfish and } \\
\text { bullheads) }\end{array}$ & 2 & 1 & & & & & \\
\hline $\begin{array}{l}\text { Percidae } \\
\text { (perch) }\end{array}$ & 1 & & & & & & \\
\hline
\end{tabular}

river downstream from Post Falls Dam exceeds Idaho's and Washington's coldwater criteria (fig. 5). The fishery at this site consists mostly of warmwater species such as sunfish, minnows, and bullheads. During the summer, the Spokane River loses water to the SVRP aquifer in the upper parts of the study reach and receives cooler water from the SVRP aquifer in the downstream reach (Box and Wallis, 2002). Near river mile 85 at Sullivan Road bridge, cool SVRP aquifer water with temperatures

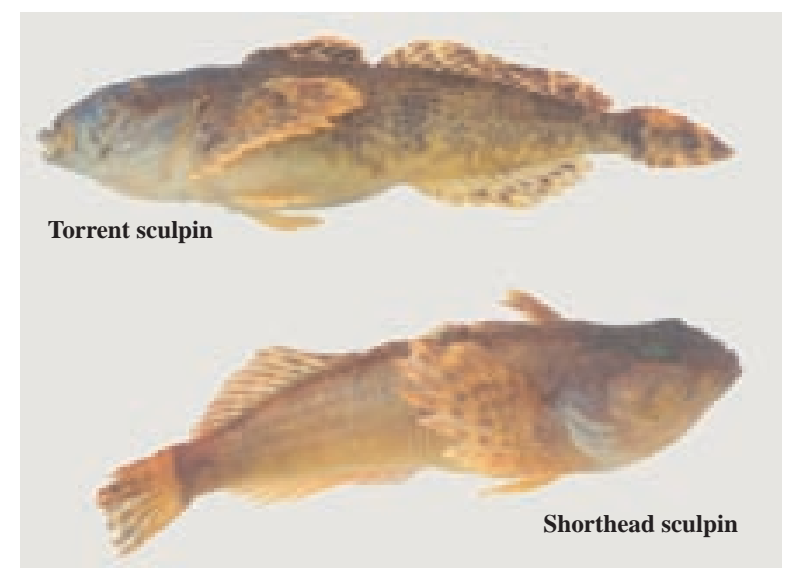

Figure 6. Sculpin (a bottom-feeding native fish), which are especially sensitive to metals (Maret and MacCoy, 2002), were found at only a few sites and in low numbers in the Spokane River. between 8 and 10 degrees Celsius (Rod Caldwell, U.S. Geological Survey, written commun., 2002) flows into the river, providing habitat for coldwater salmonids such as chinook salmon, cutthroat, brown, and rainbow trout (table 2).

Fish abundance was analyzed for individuals and species, and a population summary was calculated using 10 fish metrics (Mebane and others, 2003) that are useful for evaluating river conditions in the Pacific Northwest. The metrics are number of coldwater native species, number of cottid (sculpin) age classes (fig. 6), percent sensitive native individuals, percent coldwater individuals, percent tolerant individuals, number of alien species, percent common carp individuals, number of salmonid age classes, catch per unit effort (fish per minute of electrofishing), and percent selected anomalies. Each metric is given a value and all are summed to provide an IBI score ranging from 0 to 100 for each site. According to Mebane and others (2003), sites with IBI scores between 75 and 100 exhibit high biotic integrity with minimal disturbance and possess an abundant and diverse assemblage of native coldwater species. Sites with scores between 50 and 74 exhibit somewhat lower quality where alien species occur more frequently and the assemblage is dominated by coolwater, native spe- 


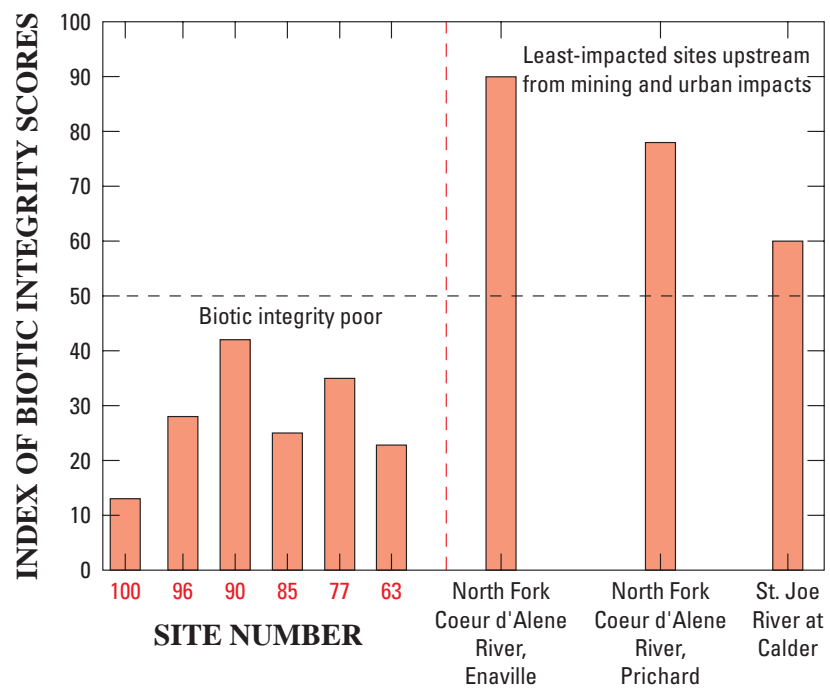

Figure 7. IBI scores for sites where fish were collected, Spokane River, Idaho and Washington, and for least-impacted sites, Idaho. (Site numbers shown in figure 1; data for least-impacted sites are given in report by Maret and others, 2001; scores based on 10 fish metrics given in report by Mebane and others, 2003)

cies. Sites with scores less than 50 indicate poor biotic integrity where coldwater and sensitive species are rare or absent, and where tolerant fish predominate. Sites with scores below 50 generally do not support a coldwater fishery. The Spokane River fish index scores indicate poor biotic integrity at all sites and sculpins were rare or absent. Index scores for the Spokane River, as well as those for least-impacted sites, are shown in figure 7.

\section{Contaminants}

Metals and organic contaminants have been measured at varying concentrations in water, sediment, and tissue of fish in the Spokane River. Elevated zinc has been measured in surface water between Post Falls and 7 Mile bridge at concentrations above the acute waterquality criteria of 35 micrograms per liter in water with a hardness value of 25 milligrams per liter (U.S. Environmental Protection Agency, 1987; Clark, 2003). Low concentrations of pesticides and VOCs also have been measured in surface water at the 7 Mile bridge site (Craig Bowers, U.S. Geological Survey, written commun., 2002).

Historical mining in the Coeur d'Alene River Basin has caused increased metal concentrations downstream in the Spokane River water, sediment, and fish tissue (Kadlec, 2000; Grosbois and others, 2001; Box and Wallis, 2002). Metals such as lead and zinc in streambed sediment can be harmful to aquatic organisms (Maret and others, in press). The PEL at which lead exposure would cause frequent adverse effects to aquatic organisms is 91.3 milligrams per kilogram, or ppm dry weight (Washington State Department of Ecology, 2002). The concentration of lead measured in 1998 in sediment smaller than 63 microns at Post Falls was 1,620 ppm dry weight, which exceeded the PEL. A lead concentration of $47.3 \mathrm{ppm}$ measured in sediment at the 7 Mile bridge site that same year was below the PEL but still considered elevated. In 1998, the concentration of zinc in sediment at Post Falls (3,210 ppm) and 7 Mile bridge (319 ppm) exceeded the PEL of 315 ppm (Washington State Department of Ecology, 2002).

Concentrations of lead and zinc in tissue of caddisflies (the main diet of many fish species) from the Spokane River were 5 times the average concentrations in tissue of caddisflies from least-impacted sites. The concentrations in caddisflies collected in the Spokane River in 1999 were 3 micrograms per gram for lead and 180 micrograms per gram for zinc (Maret and others, in press) (figs. 8 and 9).

Elevated concentrations of metals from mining and PCBs from industrial and urban sources have been measured in tissue of fish from the Spokane River over the past 10 years (Johnson and others, 1994; Johnson, 1999; Johnson, 2000; Kadlec, 2000; MacCoy, 2001; Maret and MacCoy, 2002). Metal concentrations in whole fish were elevated compared with concentrations in fish measured during national surveys (Johnson and others, 1994).

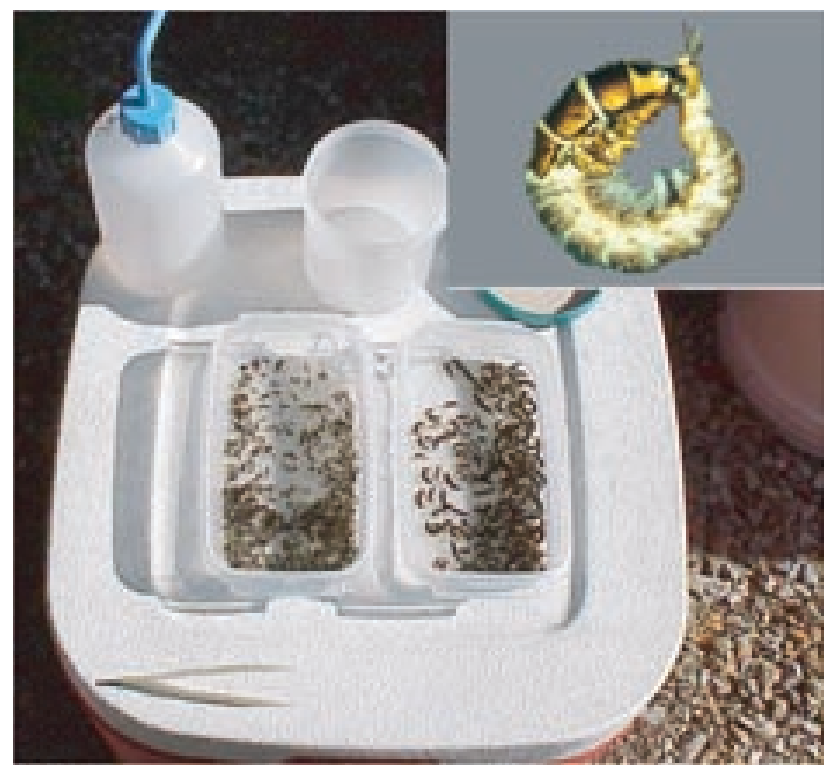

Figure 8. Collection trays for caddisfly (Hydropsyche sp.) tissue analyzed for metals. 


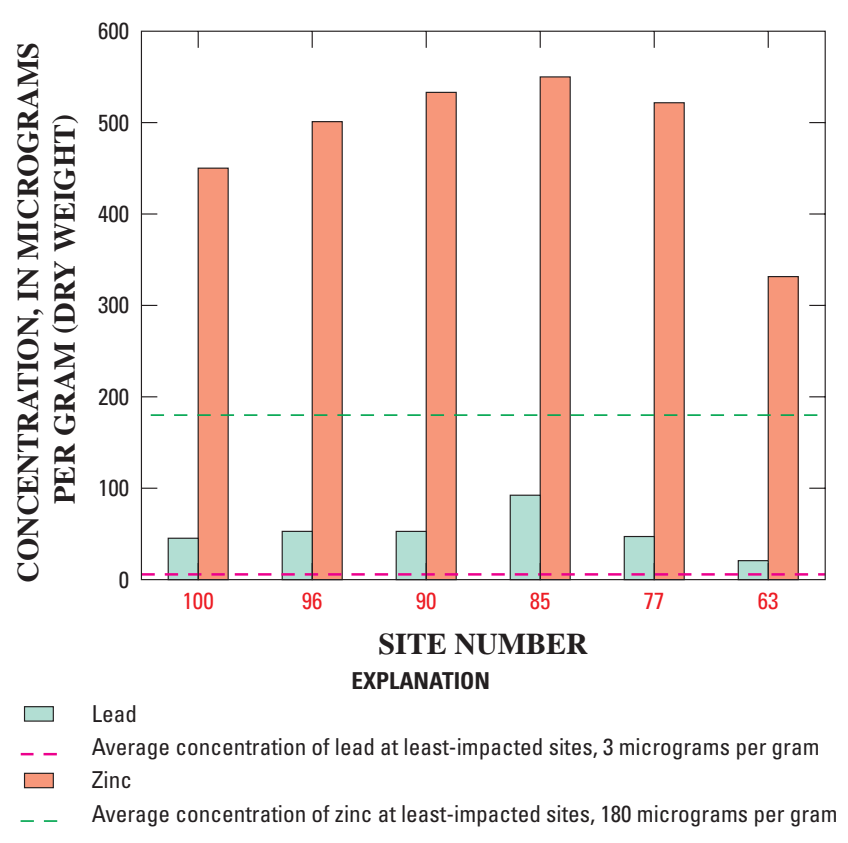

Figure 9. Concentrations of lead and zinc measured in tissue of caddisflies collected from sites on the Spokane River, Idaho and Washington, 1999, compared with average concentrations in tissue of caddisflies collected from least-impacted sites, Idaho. (Site numbers shown in figure 1; data for least-impacted sites are given in report by Maret and others, 2001)

Concentrations of lead and PCBs in fish tissue pose a threat to the public who eat fish caught between the Idaho/Washington State line and 7 Mile bridge site. PCBs in sportfish ranged from 70 to 1,610 micrograms per kilogram, or ppb (MacCoy, 2001), during this study and exceeded the human consumption criterion of $5 \mathrm{ppb}$ for edible fish tissue (U.S. Environmental Protection Agency, 1999). In response to these high concentrations of lead and PCBs in fish tissue, a fish advisory for sections of the Spokane River was issued by the Washington State Departments of Ecology and Health (1999).

PCB concentrations in tissue of whole fish from the Spokane River near Post Falls (270 ppb) and Otis Orchards (500 ppb) ranked in the top 25 percent of concentrations in the 205 fish collected from streams in mixed land-use areas across the Nation but ranked far below the highest concentrations (in excess of 10,000 $\mathrm{ppb}$ ) in tissue of fish from rivers in the Northeast (Lisa Nowell, U.S. Geological Survey, written commun., 2002, NAWQA data from 1991 and 1994 study units).

\section{Conclusions}

- Aquatic organisms in the Spokane River are affected by multiple stressors (metals, PCBs, and temperature).

- Exposure risk of aquatic organisms to elevated temperature and contaminants, such as metals and PCBs, depends on where impairment occurs in the river and the type of organism exposed.

- Major groups of native aquatic fauna, such as stoneflies and sculpins, are rare or absent in the Spokane River.

- The brevity of sampling for this study did not allow adequate determination of the extent or permanence of contamination or impairment, nor did it allow for determination of the most important stressors. Further studies targeting specific ecological indicators of various pollutants are needed to identify those stressors that are most limiting to aquatic organisms.

—Dorene E. MacCoy and Terry R. Maret

\section{References Cited}

Box, S.E., and Wallis, J.C., 2002, Surficial geology along the Spokane River, Washington and its relationship to the metal content of sediments (Idaho-Washington Stateline to Latah Creek confluence): U.S. Geological Survey Open-File Report 02-126, $50 \mathrm{p}$.

Clark, G.M., 2003, Occurrence and transport of cadmium, lead, and zinc in the Spokane River Basin, Idaho and Washington, water years 1999-2001: U.S. Geological Survey Water-Resources Investigations Report 02-4183, $37 \mathrm{p}$.

Cuffney, T.F., Gurtz, M.E., and Meador, M.R., 1993, Methods for collecting benthic invertebrate samples as part of the National Water-Quality Assessment Program: U.S. Geological Survey Open-File Report 93-406, 66 p.

Grosbois, C.A., Horowitz, A.J., Smith, J.J., and Elrick, K.A., 2001, The effect of mining and related activities on the sediment-trace element geochemistry of Lake Coeur d'Alene, Idaho, USA, Part III, Downstream effects-the Spokane River Basin: Hydrological Processes, v. 15, p. 855-875.

Johnson, A., 1999, Metals and PCB analysis of Spokane River fish and crayfish samples collected in 1999, quality assurance project plan: Olympia, Wash., Washington State Department of Ecology, Environmental Assessment Program, $10 \mathrm{p}$. 
2000, Reconnaissance survey on metals, semivolatiles, and PCBs in sediment deposits behind Upriver Dam, Spokane River: Olympia, Wash., Washington State Department of Ecology, Publication no. 00-03-021, $19 \mathrm{p}$.

Johnson, A., Serdar, D., and Davis, D., 1994, Results of 1993 screening survey on PCBs and metals in the Spokane River: Olympia, Wash., Washington State Department of Ecology, Environmental Investigations and Laboratory Services Program, 29 p.

Kadlec, M., 2000, Ecological risk analysis of elevated metal concentrations in the Spokane River, Washington: Olympia, Wash., Prepared for the State of Washington Department of Ecology, Toxics Cleanup Program, Contract no. C0000233, 78 p.

MacCoy, D.E., 2001, PCBs in tissue of fish from the Spokane River, Washington, 1999: U.S. Geological Survey Fact Sheet FS-067-01, 6 p.

Maret, T.R., Cain, D.J., MacCoy, D.E., and Short, T.M., in press, Response of benthic invertebrate assemblages to metals exposure and bioaccumulation associated with hard-rock mining in Northwest streams, U.S.A.: Journal of the North American Benthological Society.

Maret, T.R., and MacCoy, D.E., 2002, Fish assemblages and environmental variables associated with hard-rock mining in the Coeur d'Alene River Basin, Idaho: Transactions of the American Fisheries Society, v. 131, no. 5, p. 865-884.

Maret, T.R., MacCoy, D.E., Skinner, K.D., Moore, S.E., and O'Dell, I., 2001, Evaluation of macroinvertebrate assemblages in Idaho rivers using multimetric and multivariate techniques, 1996-98: U.S. Geological Survey WaterResources Investigations Report 01-4145, 69 p.

Meador, M.R., Cuffney, T.F., and Gurtz, M.E., 1993, Methods for sampling fish communities as part of the National Water-Quality Assessment Program: U.S. Geological Survey Open-File Report 93-104, 40 p.

Mebane, C.A., Maret, T.R., and Hughes, R.M., 2003, An index of biological integrity (IBI) for Pacific Northwest Rivers: Transactions of the American Fisheries Society, v. 132, no. 2, p. 239-261.

Porter, S.D., Cuffney, T.F., Gurtz, M.E., and Meador, M.R., 1993, Methods for collecting algal samples as part of the National Water-Quality Assessment Program: U.S. Geological Survey Open-File Report 93-409, 39 p.

Tornes, L.H., 1997, National Water-Quality Assessment Program-Northern Rockies Intermontane Basins: U.S Geological Survey Fact Sheet FS-158-97, 4 p.

U.S. Environmental Protection Agency, 1987, Ambient water quality criteria for zinc, 1987: Washington, D.C., U.S. Environmental Protection Agency, EPA-440/5-87-003, $213 \mathrm{p}$.

1999, Water quality standards, establishment of numeric criteria for priority toxic pollutants, States' compliance-revision of polychlorinated biphenyls (PCBs)

criteria, final rule: Federal Register, 40 CFR, Part 131, p. 61181-61196.

2002, Draft EPA Region 10 guidance for Pacific

Northwest State and Tribal temperature water quality standards: accessed October 1, 2003, at URL http://yosemite.epa.gov/R10/WATER.NSF/

Washington State Department of Ecology, 1995, Department of Ecology 1993-94 investigation of PCBs in the Spokane River: Olympia, Wash., Toxic Investigations Section, Environmental Investigations and Laboratory Services Program, Publication no. 95-310, 54 p., 5 apps.

1997, Chapter 173-201A WAC, Water quality standards for surface waters of the State of Washington (revised Nov. 18, 1997): Olympia, Wash., accessed Octber 1, 2003, at URL http://www.ecy.wa.gov/biblio/wac173201a.html

2002, Development of freshwater sediment quality values for use in Washington State, appendix $\mathrm{H}$, numeric SQV's for freshwater sediments: Washington Department of Ecology, Sediment Management Unit, Publication no. 02-09-050, 2 p.

Washington State Departments of Ecology and Health, 1999, Health advisory for Spokane River fish consumption: Spokane, Wash., accessed October 1, 2003, at URL http://www.srhd.org/safety/environment/pdf/SpokaneRiver FishAdvisory.pdf

Watson, V., and Gestring, B., 1996, Monitoring algae levels in the Clark Fork River: Intermountain Journal of Sciences, v. 2, no. 2, p. 17-26.

Welch, E.B., Horner, R.R., and Patmont, C.R., 1989, Prediction of nuisance periphytic biomass: A management approach: Water Resources, v. 23, no. 4, p. 401-405.

Woods, P.F., 2000, Concentrations and loads of cadmium, lead, zinc, and nutrients measured during the 1999 water year within the Spokane River Basin, Idaho and Washington: U.S. Geological Survey Open-File Report 00-441, 32 p.

Youngs, J.W., 1996, The Fair and the Falls: Spokane's Expo '74, Transforming an American Environment: Cheney, Wash., Eastern Washington University Press, 627 p.

\section{ABBREVIATIONS USED IN THIS REPORT:}

CHLA

IBI

NAWQA

NROK

PCBs

PEL

$\mathrm{ppb}$

ppm

SVRP

USEPA

USGS

VOCs

WDOE chlorophyll- $a$ Index of Biotic Integrity National Water-Quality Assessment Northern Rockies Intermontane Basins polychlorinated biphenyls Probable Effect Level parts per billion parts per million Spokane Valley-Rathdrum Prairie U.S. Environmental Protection Agency U.S. Geological Survey volatile organic compounds Washington State Department of Ecology 